\title{
ANTIOXIDANT ACTIVITY AND NUTRACEUTICAL POTENTIAL OF SELECTED NEPALESE WILD EDIBLE FRUITS
}

\author{
Santoshi Bhusal $^{* * * *}$, Deepak Raj Pant", Giri Prasad Joshi*, Minu Adhikari**, Jay Kant Raut ${ }^{* *}$, Manish \\ Raj Pandey $^{* * *}$ and Lok Ranjan Bhatt ${ }^{* *}$ \\ ${ }^{*}$ Central Department of Botany, Tribhuvan University, Kirtipur, Nepal. \\ ** Biological Resources Unit, Faculty of Science, Nepal Academy of Science and Technology, Khumaltar, Lalitpur, \\ Nepal. \\ ${ }^{* * *}$ National Trust for Nature Conservation, Khumaltar, Lalitpur, Nepal.
}

\begin{abstract}
Wild edible fruits play an important role in the nutrition of rural people especially in the hilly and mountainous region, where the wild fruits could be the only source to consume. Though wild edible fruits are widely utilized throughout the country, little works have been done in Nepal on their nutritional and phytochemical analysis. The main objective of this study was to evaluate the antioxidant activity and nutraceutical potential of the selected wild edible fruits. The fruit samples were extracted in appropriate solvents and all the analyses were done in triplicates using 96 well ELISA plate reader. Nutritionally, Rubus acuminatus was found to be rich in Vitamin C $(0.78 \pm 0.01 \mathrm{mg} / \mathrm{g})$ over other fruits. Protein content was found to be high in Berberis napaulensis $(2.26 \pm 0.71 \%)$ and R. ellipticus showed greater lipid $(0.15 \pm 0.01 \%)$ and $\beta$-carotene content $(1.08 \pm 0.01 \mathrm{mg} / 100 \mathrm{mg}) . R$. acuminatus was found to have high flavonoid content $(9.26 \pm 0.40 \mathrm{mg} \mathrm{QE} / \mathrm{g})$ and exhibited higher antioxidant activity while B. angulosa $(29.67 \pm 2.28 \mathrm{mg}$ $\mathrm{GAE} / \mathrm{g}$ ) had the highest phenolic content.
\end{abstract}

Keywords: Wild edible fruits; Radical scavenging activity; Phenolic content; Flavonoid content.

\section{INTRODUCTION}

Fruits, including the wild edibles are good source of carbohydrates, fibers, minerals, vitamins, essential dietary micronutrients, and more recently they have been recognized as important sources of phytochemicals that individually, or in combination, may benefit human health 1,2 . The nutritional value of fruits depend on their composition, which shows wide range of variation, depending on the species, cultivar, maturity and even cultivation conditions ${ }^{3}$. Interestingly, wild edible fruits (WEFs) are found to be nutritionally superior over the cultivated ones ${ }^{4}$. Several studies have shown that the fruits generally possess high levels of sugars and organic acids determining their sweetness and sourness ${ }^{5,6}$. Berries, which contain high amounts of bioactive phytochemicals, particularly polyphenolic antioxidants, are the focus of many studies as they are considered as valuable molecules which may reduce the risk of non-communicable diseases, such as cardiovascular disorders, cancers and others ${ }^{7,8,9}$.

Antioxidants derived from plants including wild edible fruits can enhance the endogenous antioxidant system and reduce oxidative stress and the risk of chronic diseases $^{10,11,12}$. The addition of WEFs with high antioxidant capacity can increase the nutritional value of the food/nutraceuticals and improve their organoleptic properties $^{13}$. They have huge potential as sources of natural antioxidants, food supplements, nutrients and health promoting phytochemicals ${ }^{11,13,14,15}$. Antioxidant activity and nutritional composition of wild edible fruits have been reported from the various parts of the world. However, such information on Nepalese wild edible fruits is scarce $16,17,18$. We herein reported antioxidant activity and nutritional composition of selected wild edible fruits from Parbat district and Gaurishankar Conservation Area.

\section{MATERIALS AND METHODS}

\section{Plant material}

Rubus acuminatus was from Parbat district while rests of the sample were collected from Gaurishankar Conservation Area, which is situated in northern part of Central Nepal. Fruits commonly used by local people and that also have income generating opportunities were selected. Samples were collected for nutritional and phytochemical analysis. Fruits which were taken in this research work were: Berberis angulosa, Berberis asiatica, Berberis thomsoniana, Berberis napaulensis, Eriobotrya dubia, Myrica esculenta, Rubus acuminatus and Rubus ellipticus.

\section{Collection and identification}

Bunches of mature fruits were collected during their fruiting period during March-September. Selected samples were photographed in their natural habitat and GPS locations were recorded. Herbariums were prepared and were deposited at NAST and identified with the help of standard literature and herbarium specimens deposited at TUCH and KATH. 
Table 1. List of wild edible fruit samples with their common names and GPS locations

\begin{tabular}{|c|c|c|c|c|}
\hline Scientific Name & Common Name & $\begin{array}{l}\text { Altitude } \\
\text { (m) }\end{array}$ & Latitude & Longitude \\
\hline Berberis angulosa Wall. ex Hook. f. \& Thoms. & Chutro & 3747 & $\mathrm{~N} 27^{\circ} 45.460^{\prime}$ & ${\mathrm{E} 086^{\circ} 02.031^{\prime}}^{\prime}$ \\
\hline Berberis asiatica Roxb. ex DC. & Chutro & 2037 & $\mathrm{~N} 27^{\circ} 52.567^{\prime}$ & ${\mathrm{E} 086^{\circ} 14.114^{\prime}}^{\prime}$ \\
\hline Berberis thomsoniana C.K. Schneid. & Chutro & 3747 & $\mathrm{~N} 27^{\circ} 45.460^{\prime}$ & ${\mathrm{E} 086^{\circ} 02.031^{\prime}}^{\prime}$ \\
\hline Berberis napaulensis (DC) Laferr & Jamane mandro & 2506 & $\mathrm{~N} 27^{\circ} 53.194^{\prime}$ & ${\mathrm{E} 086^{\circ} 15.327^{\prime}}^{\prime}$ \\
\hline Eriobotrya dubia (Lindl.) Decne. & Jure kafal & 2216 & $\mathrm{~N} 27^{\circ} 53.212^{\prime}$ & ${\mathrm{E} 086^{\circ} 14.969^{\prime}}^{\prime}$ \\
\hline Rubus acuminatus Sm. & Fusre aiselu & 2579 & $\mathrm{~N} 27^{\circ} 21.191^{\prime}$ & ${\mathrm{E} 086^{\circ} 37.600^{\prime}}^{\prime}$ \\
\hline Rubus ellipticus $\mathrm{Sm}$. & Aiselu & 2100 & $\mathrm{~N} 27^{\circ} 52.147^{\prime}$ & ${\mathrm{E} 086^{\circ} 14.500^{\prime}}^{\prime}$ \\
\hline Myrica esculenta Buch.-Ham. ex D. Don & Kaphal & 2200 & $\mathrm{~N} 27^{\circ} 53.212^{\prime}$ & E086²14.969' \\
\hline
\end{tabular}

\section{Preparation of samples}

Healthy fruits were carefully plucked from the bunch and air dried for about 20 days to remove moisture content. Then after, oven dried for a day at $37^{\circ} \mathrm{C}$. Seeds were separated from fruit pulps using forceps and needles. Then the samples were fine powered with the help of grinder and stored in dry, air-tight plastic containers with proper labeling.

\section{Preparation of fruit extract}

One gram of finely powered fruit pulp was poured into conical flask and $20 \mathrm{~mL}$ of methanol was added to it. Well labeled flasks were kept into shaking incubator (Innovative life science tool) at $37^{\circ} \mathrm{C}$ for 24 hours with gentle shaking $(100 \mathrm{rpm})$. After 24 hours, the samples were filtered through Whatman No. 1 filter paper (GE Healthcare UK Limited). The residue was subjected to extraction with additional $20 \mathrm{~mL}$ of methanol in the same manner and then filtered. Both the filtrates were mixed and the final volume was made up to $40 \mathrm{~mL}$ adding methanol in falcon tubes. All the methanolic extracts were stored in refrigerator at $4{ }^{\circ} \mathrm{C}$ until future use.

Similarly for the protein content analysis, 0.2 gram of sample was weighed and poured in conical flask and 20 $\mathrm{mL}$ of double distilled water was added in it. Then the conical flasks were kept into shaking incubator at $50{ }^{\circ} \mathrm{C}$ for 24 hours with $100 \mathrm{rpm}$. Filtration was done and final volume was made up to $20 \mathrm{~mL}$.

\section{Antioxidant activity}

Antioxidant activity of methanolic extracts of all samples was assessed on the basis of radical scavenging effect of the stable 1, 1-diphenyl -2 picrylhydrazyl (DPPH) (Sigma-Aldrich, Germany) free radical activity following the method of Blois ${ }^{19}$ modified by Singh et.al. ${ }^{20}$. Ascorbic acid was used as standard. Plant extracts of various concentrations and the standard was prepared on clean and dry ependorf tubes. An aliquot of the sample $(100 \mu \mathrm{L})$ was introduced into 96 well ELISA plate followed by $100 \mu \mathrm{L}$ DPPH solution $(0.2 \mathrm{mM})$. Control was prepared as above but without fruit extract and methanol was used as blank. Sample was introduced in triplicate form for the reproducible result. Well plate was incubated in dark for half an hour and absorbance was taken in an ELISA reader (Epoch 2 plate reader, Biotech) at $517 \mathrm{~nm}$.

Radical scavenging activity was calculated using the formula:

Radical scavenging activity (RSA) $\%=($ Abs. control Abs. sample/Abs. control)*100

\section{Total phenolic content}

Total phenolic content of all methanol extract samples was determined by using the Folin-Ciocalteau phenol reagent with slight modifications ${ }^{[21]}$. In brief, extract sample was diluted 10 times and an aliquot of the diluted samples $(30 \mu \mathrm{L})$ was introduced into 96 well ELISA plate followed by $150 \mu \mathrm{L}$ Folin-Ciocalteu reagent (Merck Specialities Private Limited) and $120 \mu \mathrm{L} 0.7 \mathrm{M} \mathrm{Na}_{2} \mathrm{CO}_{3}$ (LOBA Chemie.). Positive control was prepared by replacing methanol in place of sample. Now the well plate was incubated in dark for half an hour and absorbance was measured at $765 \mathrm{~nm}$ against that of methanol (blank) using ELISA reader. Gallic acid was used as standard for the reference. Different concentration series of gallic acid (Fisher scientific) was made and used as reference standard to prepare calibration curve. Based on the calibration curve obtained from gallic acid, concentration of phenolic content of the plant sample was calculated as milligrams of the gallic acid equivalent per gram of the dry mass (mg GAE/g).

\section{Total flavonoid content}

Total flavonoid content was estimated using the aluminium chloride method ${ }^{22}$ with slight modifications. First of all extract samples were diluted to $2.5 \mathrm{mg} / \mathrm{mL}$ and an aliquot $(100 \mu \mathrm{L})$ of the diluted samples were introduced into 96 well ELISA plate followed by $100 \mu \mathrm{L}$ $0.1 \mathrm{M} \mathrm{AlCl} \mathrm{Al}_{3}$ (SD fine- Chem Ltd, Mumbai). Positive control was prepared by replacing the sample with methanol while methanol was taken as blank. The well plate was then incubated in dark for an hour and absorbance was measured at $510 \mathrm{~nm}$ using ELISA reader. Same experiment was also done with various concentration series of quercetin (Sigma-Aldrich). Based on the calibration curve obtained from series of quercetin concentration, total flavonoid content of the plant sample was calculated and expressed in terms of the milligrams 
of the quercetin equivalent per gram of the dry mass (mg $\mathrm{QE} / \mathrm{g})$.

\section{Total protein content}

Total protein content of the aqueous extract of samples was determined following Fanglian, He with slight modifications ${ }^{23}$. Freshly prepared Bradford reagent was used to quantify the protein content. $100 \mu \mathrm{L}$ sample was thoroughly mixed with one $\mathrm{mL}$ Bradford reagent in a two $\mathrm{ml}$ polypropylene tubes and then vortexes. Then $200 \mu \mathrm{L}$ of the mixture was introduced into 96 well plate and incubated for 2- 10 minutes and absorbance was taken at $595 \mathrm{~nm}$ against blank in ELISA reader. Standard stock of bovine serum albumin (HIMEDIA Laboratories Private Ltd., Mumbai) $\mathrm{mg} / \mathrm{mL}$ ) was prepared and calibration curve was plotted with concentration ranging from $10 \mu \mathrm{g}$ $/ \mathrm{mL}-1000 \mu \mathrm{g} / \mathrm{mL}$.

\section{Lipid content}

Lipid content was determined by using semi-continuous method $^{24}$. For this, one gram of the sample was extracted with $200 \mathrm{~mL}$ petroleum ether (HIMEDIA Laboratories Private Ltd., Mumbai) on a Soxhlet apparatus (S.M Scientific Instruments Pvt. ltd.) for 10 hours. After 10 hour, petroleum ether was removed by evaporation with the help of Rota-evaporator and the residue of the lipid was weighed. Residue was subtracted from the weight of sample taken which gave the content of lipid and the results were expressed in percentage.

\section{Estimation of carotenoids}

To determine the content of $\beta$ - carotene and lycopene, the previous method was followed with slight modifications ${ }^{25}$. In brief, 0.1 gram samples were taken and shaken with $10 \mathrm{~mL}$ of acetone- hexane mixture in the ratio of 4:6 for one minute and filtered through Whatman No. 1 filter paper. Now, the samples were introduced into 96 well ELISA plate and absorbance was measured at 453, 505, 645 and $663 \mathrm{~nm}$. Content of $\beta$-carotene and lycopene was calculated according to the following equations:

Lycopene $(\mathrm{mg} / 100 \mathrm{~mL})=-0.0458 \mathrm{~A}_{663}+0.372 \mathrm{~A}_{505}-$ $0.0806 \mathrm{~A}_{453}$ and,

$\beta$ - Carotene $(\mathrm{mg} / 100 \mathrm{ml})=0.216 \mathrm{~A}_{663}-0.304 \mathrm{~A}_{505}+$ $0.452 \mathrm{~A}_{453}$.

Table 2. Antioxidant activity of samples and standard by DPPH assay

\section{Vitamin $\mathbf{C}$ content}

Vitamin-C content was determined following previous method with slight modifications ${ }^{26}$. Firstly, the samples were extracted with 1\% metaphosphoric acid (HIMEDIA Laboratories Private Ltd., Mumbai) for 10 hour at room temperature and the solutions was then filtered through Whatman No. 1 filter paper. To quantify the vitamin C content, an aliquot of the samples $(20 \mu \mathrm{l})$ were introduced into 96 well ELISA plate followed by $180 \mu \mathrm{L} 2$, 6dichloroindophenol (HIMEDIA Laboratories Private Ltd., Mumbai) and immediately, the absorbance was measured at $515 \mathrm{~nm}$ using ELISA reader against blank. Authentic L- ascorbic (CDH Laboratories reagents) acid was used as standard. Concentration series was prepared and calibration curve was plotted. Based on the calibration curve, content of vitamin $\mathrm{C}$ was calculated and result was expressed as milligrams per gram of the dry mass.

\section{Statistical analysis}

All the measurements were taken in triplicates and values were reported as mean $\pm \mathrm{SD}$. Statistical significance of differences in mean values of different parameters were determined by using one way analysis of variance (ANOVA). All the analyses were done using Microsoft Excel 2013.

\section{RESULTS}

\section{Antioxidant activity}

DPPH radical scavenging activity was used to quantify the free radical scavenging activity. In the present study, samples exhibited concentration dependent radical scavenging activity (Table 2). Among all samples, $R$. ellipticus showed the strongest activity $(83.55 \pm 3.39 \%)$ at lowest concentration tested while $B$. napaulensis was found to have weak scavenging activity. However, at 10 $\mathrm{mg} / \mathrm{g}$ concentration all the samples showed similar scavenging activity except $B$. napaulensis. As the concentration increases, scavenging activity of samples gradually increases. Ascorbic acid which was used as a standard in this study exhibited $95 \%$ radical scavenging activity at $1 \mathrm{mg} / \mathrm{mL}$ concentration.

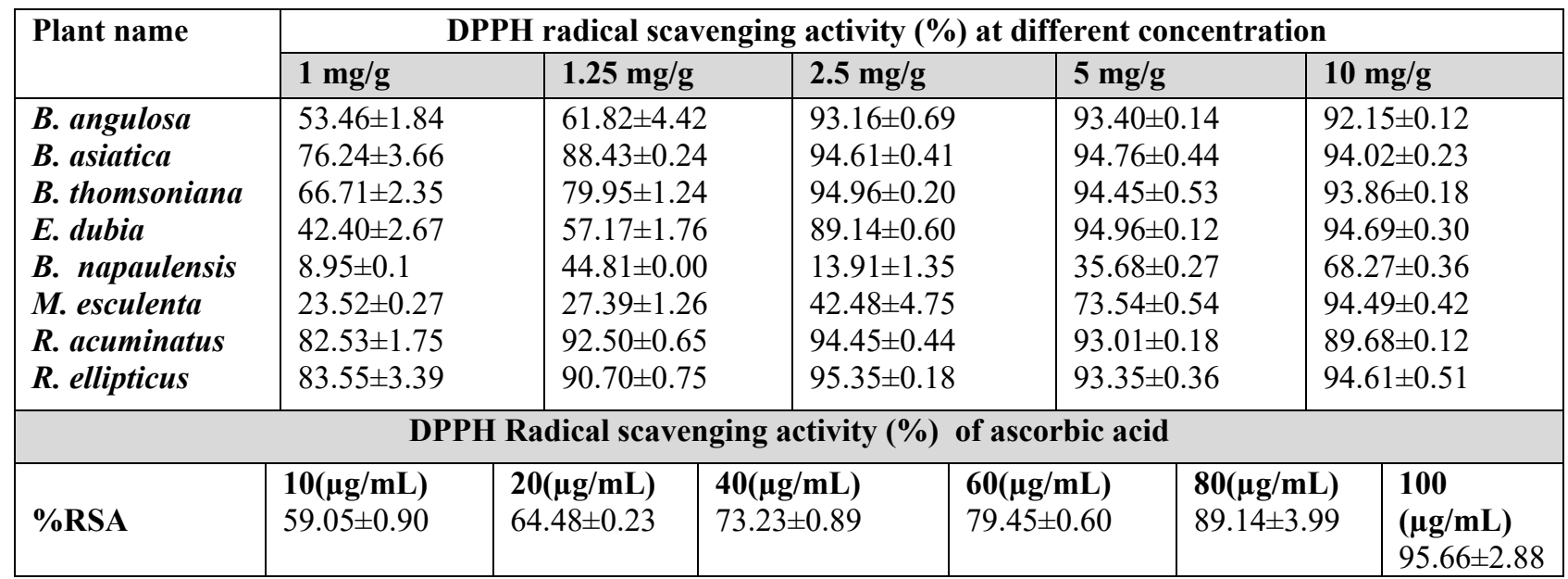




\section{Total phenolic and flavonoid content}

Total phenolic content of samples varied from $10.19 \pm$ 0.69 to $29.67 \pm 2.28 \mathrm{mg}$ GAE$/ \mathrm{g}$ dry weight of sample. The highest phenolic content was found in B. angulosa while the lowest was found in B. napaulensis. TPC of other fruit samples lies in between these two values (Table 3). Similarly, variation was obtained in total flavonoid content of selected samples. The highest amount of flavonoid content was found to be $9.26 \pm 0.40$ $\mathrm{mg}$ QE/g dry weight of sample for $R$. acuminatus, while the lowest was found to be $1.54 \pm 0.03 \mathrm{mg} Q \mathrm{QE} / \mathrm{g}$ dry weight of sample for E. dubia (Table 3). Total phenolic and flavonoid significantly varied among the fruit samples $(\mathrm{P}<0.001)$.

Table 3. Total phenolic and flavonoid content of wild edible fruits

\begin{tabular}{|l|c|c|}
\hline Sample & TPC(mg GAE/g) & TFC(mg QE/g) \\
\hline B. angulosa & $29.67 \pm 2.28$ & $7.55 \pm 0.56$ \\
\hline B. asiatica & $23.59 \pm 0.54$ & $6.44 \pm 0.79$ \\
\hline B. thomsoniana & $23.31 \pm 1.59$ & $1.54 \pm 0.03$ \\
\hline E. dubia & $17.11 \pm 1.35$ & $2.11 \pm 0.12$ \\
\hline B. napaulensis & $10.19 \pm 0.69$ & $4.56 \pm 0.17$ \\
\hline M. esculenta & $13.42 \pm 0.71$ & $9.26 \pm 0.40$ \\
\hline R. acuminatus & $25.24 \pm 2.41$ & $4.68 \pm 0.66$ \\
\hline R. ellipticus & $19.72 \pm 0.43$ & \\
\hline
\end{tabular}

\section{Nutritional analysis}

Protein, vitamin- $\mathrm{C}$, lipid, $\beta$ carotene and lycopene content were quantified for nutritional analysis (Table 4). Protein content of fruits varied from $0.79 \pm 0.14$ (B. thomsoniana) to $2.26 \pm 0.71$ percent (B. napaulensis) while vitamin $\mathrm{C}$ content varied from $0.19 \pm 0.01$ (R. ellipticus) to $0.78 \pm$
0.01 (R. acuminatus) $\mathrm{mg} \mathrm{AA} / \mathrm{g}$ dry weight of the sample. $\beta$ - carotene, a precursor of vitamin A was detected in very negligible amount in almost all fruit samples. $\beta$-carotene content ranged from $0.04 \pm 0.02$ ( $R$. acuminatus) to $0.11 \pm$ 0.01 ( $R$. ellipticus). Similarly, the values obtained for lipid content was also found in very negligible amount.

Table 4. Protein, Vitamin C, Lipid, $\beta$-carotene and Lycopene content of wild edible fruits

\begin{tabular}{|c|c|c|c|c|c|}
\hline Plant name & $\begin{array}{l}\text { Protein content } \\
\qquad(\%)\end{array}$ & $\begin{array}{c}\text { Vitamin C } \\
(\mathrm{mg} / \mathrm{g})\end{array}$ & Lipid (\%) & $\begin{array}{c}\beta \text {-Carotene } \\
(\mathrm{mg} / \mathrm{g})\end{array}$ & $\begin{array}{l}\text { Lycopene } \\
\text { (mg/g) }\end{array}$ \\
\hline B. angulosa & $1.01 \pm 0.41$ & $0.58 \pm 0.01$ & $0.025 \pm 0.01$ & $0.05 \pm 0.02$ & $0.03 \pm 0.01$ \\
\hline B. asiatica & $1.43 \pm 0.58$ & $0.31 \pm 0.01$ & $0.035 \pm 0.01$ & $0.05 \pm 0.01$ & $0.03 \pm 0.01$ \\
\hline B. thomsoniana & $0.79 \pm 0.14$ & $0.39 \pm 0.01$ & $0.020 \pm 0.01$ & $0.05 \pm 0.01$ & $0.04 \pm 0.01$ \\
\hline E. dubia & $1.28 \pm 0.29$ & $0.27 \pm 0.01$ & $0.030 \pm 0.01$ & $0.07 \pm 0.01$ & $0.04 \pm 0.01$ \\
\hline B. napaulensis & $2.26 \pm 0.71$ & $0.22 \pm 0.01$ & $0.035 \pm 0.01$ & $0.06 \pm 0.03$ & $0.02 \pm 0.01$ \\
\hline M. esculenta & $0.90 \pm 0.67$ & $0.21 \pm 0.02$ & $0.06 \pm 0.01$ & $0.05 \pm 0.01$ & $0.03 \pm 0.01$ \\
\hline R. acuminatus & $1.34 \pm 0.79$ & $0.78 \pm 0.01$ & $0.013 \pm 0.01$ & $0.04 \pm 0.02$ & $0.03 \pm 0.01$ \\
\hline R. ellipticus & $1.40 \pm 0.84$ & $0.19 \pm 0.01$ & $0.15 \pm 0.01$ & $0.11 \pm 0.01$ & $0.03 \pm 0.01$ \\
\hline
\end{tabular}

\section{DISCUSSION}

Antioxidant activity including phenol and flavonoid content and neutraceutical potential of selected eight wild edible fruits were evaluated and considerable amount of variation was found. Among all tested fruit samples, stronger DPPH radical scavenging activity was found in
R. ellipticus over the other fruits selected. High radical scavenging activity was shown by wild edible fruits (Berberis, Myrica, Rubus) from West Himalayan Regions of India ${ }^{27,28,29,30}$. The comparable results for different berries from other species conclude that berries are better source of antioxidants. Total phenolic content vary among the fruits while some researchers reported comparable 
results $^{31}$ and in fruits of $B$. angulosa and B. asiatica, higher phenolic content was reported.

Anthocyanins are reported as common flavonoids in fruits and account for various coloration like blue, red, violet, etc. in berries ${ }^{32}$. Total flavonoid content obtained from the previous study of $M$. esculenta and various species of Rubus are comparable to the present study ${ }^{33}$. Studies done for some fruits are comparatively higher than the value obtained in the present study ${ }^{18,27}$. It has been reported that flavonoid content depends upon biological and environmental factors ${ }^{34}$. The findings of the present study are also consistent with that of wild fruits of Indian Himalayan Region ${ }^{35}$.

Vitamin C content of B. asiatica in the present study was found similar to previous report ${ }^{36}$. Dramatic variations were found in berry fruits, with levels of ascorbic acid ranging from 0.14 to $1.03 \mathrm{mg} / \mathrm{g}$ among cultivars of raspberry, blackberry, red currant, gooseberry and cornelian cherry. The reported range of total ascorbic acid in present investigation also lies in the range reported previously $^{37}$. Ascorbic acid is now known as an antioxidant and its deficiency may cause Scurvy ${ }^{38}$. Comparable amount of ascorbic acid in these fruits can be promoted as a source of natural ascorbic acid which helps to overcome many health problems.

Protein content of some fruit samples analyzed in the present study is comparable and higher than the previous studies $^{18,36,37,38}$. $\beta$ carotene, precursor of vitamin $A$ is highly known for vision, reproduction, proper immune functions, including the deactivation of reactive oxygen species $^{39}$. However, some papers had reported similar $\beta$ carotene content for $R$. ellipticus ${ }^{40}$. It has been known that the level of carotenoids and lycopene in different fruits vary with cultivar, environmental conditions including solar radiations, growing seasons and maturity stages ${ }^{41,42}$.

Present study has focused only on eight wild edible fruits and deals mainly with quantification of nutritional and phytochemical attributes. The data obtained from this study indicates that selected wild fruits are rich in nutritive and phytochemical constituents. Additionally, higher amount of phenolics and the stronger antioxidant activity shown by selected plants can be useful in combating free radical damage.

\section{CONCLUSION}

The wild edible fruits evaluated in this study showed a range of antioxidant activity and nutritional composition. Methanolic extracts of $R$. acuminatus and $R$. ellipticus showed stronger antioxidant ability among the tested samples. Fruits are comparatively rich in protein and vitamin $\mathrm{C}$, however, contained low amount of lipid and negligible amount of carotenoids and lycopene. The present study only focused on the analysis of macronutrients. Hence, further study should be carried out on micronutrients and characterization of bioactive compounds present in the fruit samples.

\section{ACKNOWLEDGEMENT}

This study was supported by Nepal Academy of Science and Technology, Khumaltar, Lalitpur. We are thankful to National Trust for Nature Conservation, Khumaltar, Lalitpur, Nepal for the partial financial support and providing the permission for the field work in Gaurishankar Conservation Area.

\section{REFERENCES}

1. Rechkemmer, G. 2001. Funktionelle Lebensmittel-Zukunft der Ernahrung oder Marketing-Strategie. Molkerei Zeitung Welt Der Milch. 55(12/13): S-332.

2. Yahia, E. M.(Eds.). 2017. The contribution of fruit and vegetable consumption to human health. Phytochemical: Chemistry, Nutritional and Stability. 3-51.

3. Florkowski, W. J., Prussia, S. E., Shewfelt, R. L., and Brueckner, B. (Eds.). 2009. Postharvest Handling: A Systems Approach. Academic Press.

4. Burlingame, B. 2000. Wild nutrition. Journal of Food Composition and Analysis. 2(13): 99-100.

5. Sturm, K., Koron, D., and Stampar, F. 2003. The composition of fruit of different strawberry varieties depending on maturity stage. Food Chemistry. 83(3): 417-422.

6. Kafkas, E., Kosar, M., Turemis, N., and Baser, K. H. C. 2006 Analysis of sugars, organic acids and vitamin $\mathrm{C}$ contents of blackberry genotypes from Turkey. Food Chemistry. 97(4): 732736.

7. Kris-Etherton, P. M., Hecker, K. D., Bonanome, A., Coval, S. M., Binkoski, A. E., Hilpert, K. F., and Etherton, T. D. 2002. Bioactive compounds in foods: their role in the prevention of cardiovascular disease and cancer. The American Journal of Medicine. 113(9): 71-88.

8. Valko, M., Leibfritz, D., Moncol, J., Cronin, M. T., Mazur, M., and Telser, J. 2007. Free radicals and antioxidants in normal physiological functions and human disease. The International Journal of Biochemistry and Cell Biology. 39(1): 44-84.

.9. Wang, S., Melnyk, J. P., Tsao, R., and Marcone, M. F. (2011). How natural dietary antioxidants in fruits, vegetables and legumes promote vascular health. Food Research International. 44(1): 1422.

10. Packer L. and Ong A.S.H. (eds.) 1998. Biological Oxidants and Antioxidants:Molecular Mechanisms and Health Effects, AOCS Press, Champaign.

11. Ikram, E. H. K., Eng, K. H., Jalil, A. M. M., Ismail, A., Idris, S., Azlan, A., et. al. 2009. Antioxidant capacity and total phenolic content of Malaysian underutilized fruits. Journal of Food Composition and Analysis. 22(5): 388-393.

12. Huang W.Y., Cai, Y.Z., Corke, H., Sun, M. 2010. Survey of antioxidant capacity and nutritional quality of selected edible and medicinal fruit plants in Hong Kong, Journal of Food Composition and Analysis. 23: 510-517.

13. Sanchez-Bel, P., Romojaro, A., Egea, I., Pretel, M.T. 2015. Wild edible plants as potential antioxidant or nutritional supplements for beverages minimally processed, LWT - Food Science and Technology. 62: 830-837.

14. Andola, H.C., Rawal, R.S., Bhatt, I.D. 2011. Comparative studies on the nutritive and anti-nutritive properties of fruits in selected Berberis species of West Himalaya, India, Food Research International. 44:2352-2356.

15. Kubola, J. Siriamornpun, S. Meeso, N. 2011. Phytochemicals, vitamin $\mathrm{C}$ and sugar content of Thai wild fruits, Food Chemistry. 126: 972-981.

16. Bajaracharya D. 1980. Nutritive values of Nepalese edible fruits, Z Lebensm Unters Forsch. 171(5): 363-366.

17. Chalise, J.P., Acharya, K., Gurung, N., Bhusal, R.P., Gurung, R., Skalko-Basnet, N., Basnet, P. 2010. Antioxidant activity and polyphenol content in edible wild fruits from Nepal, International Journal of Food Sciences and Nutrition. 61(4):425-432.

18. Dhungel, S., Joshi, G.P., Pant, D.R. 2016. Nutritional and physicochemical study of fruit extracts of selected Berberis species in Nepal. Botanica Orientalis- - Journal of Plant Science. 10: 6-11.

19. Blois, M.S. 1958. Antioxidant Determinations by the Use of a Stable Free Radical. Nature. 181: 1199-1200. 
20. Singh, R. P., Chidambara Murthy, K. N., Jayaprakasha, G. K. 2002. Studies on the antioxidant activity of pomegranate (Punica granatum) peel and seed extracts using in vitro models. Journal of Agricultural and Food Chemistry. 50(1): 81-86.

21. Singleton, V. L., Rossi, J. A. 1965. Colorimetry of total phenolics with phosphomolybdic-phosphotungstic acid reagents. American Journal of Enology and Viticulture. 16(3): 144-158.

22. Chang, C. C., Yang, M. H., Wen, H. M., and Chern, J. C. 2002. Estimation of total flavonoid content in propolis by two complementary colorimetric methods. Journal of Food and Drug Analysis. 10(3):178-182.

23. Fanglian, He. 2012. Bradford protein assay. Bioprotocol/DOI:https://doi.org/10.21769/BioProtoc. 45 .

24. Eggers, R. in King, J. W., List, G.R.(Eds.) 1996. Supercritical fluid extraction (SFE) of oil seeds/lipids in natural products. Supercritical Fluid Technology in oil and lipid chemistry. 35-46.

25. Nagata, M., Yamashita, I. 1992. Simple method for simultaneous determination of chlorophyll and carotenoids in tomato fruit. Nippon Shokuhin Kogyo Gakkaishi. 39(10): 925-928.

26. Klein, B. P., Perry, A. K. 1982. Ascorbic acid and vitamin A activity in selected vegetables from different geographical areas of the United States. Journal of Food Science. 47(3): 941-945.

27. Akhtar, N., and Mirza, B. 2015. Phytochemical analysis and comprehensive evaluation of antimicrobial and antioxidant properties of 61 medicinal plant species. Arabian Journal of Chemistry. 11(8):1223-1235.

28. Hoshyar, R., Mahboob, Z., Zarban, A. 2016. The antioxidant and chemical properties of Berberis vulgaris and its cytotoxic effect on human breast carcinoma cells. Cytotechnology. 68(4): $1207-$ 1213.

29. Rawat, S., Jugran, A., Giri, L., Bhatt, I. D., Rawal, R. S. 2011 Assessment of antioxidant properties in fruits of $\mathrm{Myrica}$ esculenta: a popular wild edible species in Indian Himalayan region. Evidence-Based Complementary and Alternative Medicine. doi:10.1093/ecam/neq055.

30. Belwal, T., Dhyani, P., Bhatt, I. D., Rawal, R. S., Pande, V. 2016. Optimization extraction conditions for improving phenolic content and antioxidant activity in Berberis asiatica fruits using response surface methodology (RSM). Food Chemistry. 207: 115124.

31. Bakar, A., Fadzelly, M., Ismail, N. A., Isha, A., Ling, M., Lee, A. 2016. Phytochemical composition and biological activities of selected wild berries (Rubus moluccanus L., R. fraxinifolius Poir. and $R$. alpestris Blume). Evidence-Based Complementary and Alternative

Medicine, 2016 https://doi.org/10.1155/2016/2482930.

32. Yao, L. H., Jiang, Y. M., Shi, J., Tomas-Barberan, F. A., Datta N., Singanusong, R., and Chen, S. S. 2004. Flavonoids in food and their health benefits. Plant Foods for Human Nutrition. 59(3): 113-122.

33. Bhatt, I. D., Rawat, S., Badhani, A., Rawal, R. S. 2017. Nutraceutical potential of selected wild edible fruits of the Indian Himalayan region. Food Chemistry. 215: 84-91.

34. Woodhead S. 1981. Environmental and Biotic Factors Affecting the Phenolic Content of Different Cultivars of Sorghum biocolor. Journal of Chemical Ecology. 7(6): 1035- 1047.

35. Subash, C., Saklani, S., Alok K.S. 2011. Berberis asiatica future based excellent fruit in nutritional profile antimicrobial and antioxidant ingredients. International Research Journal of Pharmacy. 2(12): 213-216.

36. Pantelidis, G. E., Vasilakakis, M., Manganaris, G. A., Diamantidis, G. R. 2007. Antioxidant capacity, phenol, anthocyanin and ascorbic acid contents in raspberries, blackberries, red currants, gooseberries and Cornelian cherries. Food Chemistry. 102(3): 777-783.

37. Benzie, I. F. 2003. Evolution of dietary antioxidants. Comparative Biochemistry and Physiology Part A: Molecular \& Integrative Physiology. 136(1):113-126.

38. Abozeid, W. M., Nadir, A. S. 2012. Physicochemical and organoleptic characteristics of loquat fruit and its processing. Nature and Science. 10(6): 108-113.

39. Chytil, F. 1999. Vitamin A: not for vision only. British Journal of Nutrition. 82(3): 161-162.

40. Badhani, A., Rawat, S., Bhatt, I. D., Rawal, R. S. 2015. Variation in chemical constituents and antioxidant activity in yellow Himalayan (Rubus ellipticus smith) and hill raspberry (Rubus niveus thunb.). Journal of Food Biochemistry. 39(6): 663-672.

41. Lee, J. J., Crosby, K. M., Pike, L. M., Yoo, K. S., Leskovar, D. I. 2005. Impact of genetic and environmental variation on development of flavonoids and carotenoids in pepper (Capsicum spp.). Scientia Horticulturae. 106(3): 341-352.

42. Brandt, S., Pek, Z., Barna, E., Lugasi, A., and Helyes, L. 2006. Lycopene content and colour of ripening tomatoes as affected by environmental conditions. Journal of the Science of Food and Agriculture. 86(4): 568-572. 